\title{
Wouldn't Human Understanding be Necessary to Treat Patients with Pancreaticobiliary Disease More Effectively?
}

\author{
Sang- Heum Park ${ }^{1}$, Hoo Rim Song ${ }^{2}$, Sung Won Lee ${ }^{3}$, Tae Hoon Lee ${ }^{1}$ \\ ${ }^{1}$ Division of Gastroenterology, Department of Internal Medicine, Soonchunhyang University College of Medicine, Cheonan; ${ }^{2}$ Department of Psychiatry, \\ Myongji Hospital, Goyang; ${ }^{3}$ Division of Rheumatology, Department of Internal Medicine, Soonchunhyang University College of Medicine, Cheonan, \\ Korea
}

Human understanding is one of the three virtues that are expected of physicians in Harrison's principles of internal medicine, and it was emphasized that a Shakespearean breadth is needed to be the true physician. Recently, there has been an increase in the need for human understanding, such as a continuous increase in GB stones, an association between the patient's life events and pancreaticobiliary diseases, an increase in autoimmune disease, and a high recurrence rate after treatment. Therefore, we attempted a holistic and fundamental approach for figuring out the pathogenesis of pancreaticobiliary diseases including human habit loop and adaptive response and suggests the model for the development of pancreaticobiliary disease considering human understanding.

Korean J Pancreas Biliary Tract 2018;23(3):89-100

Keywords: Pancreaticobiliary diseases, Human understanding, Habit loop, Adaptive response

\section{Received Jul. 4, 2018 \\ Revised Jul. 9, 2018 \\ Accepted Jul. 9, 2018}

Corresponding author : Sang-Heum Park

Division of Gastroenterology, Department of Internal Medicine, Soonchunhyang University College of Medicine, 31 Suncheonhyang 6-gil, Dongnam-gu, Cheonan 31151, Korea

Tel. +82-41-570-3892 Fax. +82-41-592-3803

E-mail; pparksh@schmc.ac.kr

\section{서 론}

해리슨 내과학의 첫 페이지에 의사(physician)에게 요구되는 세 가지 덕목으로 기술적 수기 능력(technical skill), 과학적 지식(scientific knowledge), 인간 이해(human understand$\mathrm{ing}$ )가 제시되어 있다. ${ }^{1}$ 이 세 가지 덕목 가운데 기술적 수기 능력과 과학적 지식은 가시적이고 객관적이다. 그리고 실제 임상에서 환자를 진단하고 치료하는 과정에서 그 효용성과
가치를 반복적으로 경험한다. 그런데 세 번째 '인간 이해'는 비가시적이고 다소 주관적이며 시간이 필요한 내용이어서, 실제 임상 현장에서 그 의미와 필요성을 절실하게 느끼지 못하는 게 현실이다.

해리슨 내과학에서 인간 이해에 덧붙여서 소개한 것은 'Shakespearean breadth'이다. 즉, 의사에게 영국의 대문호 월리엄 세익스피어(William Shakespeare, 1564-1616)와 같은 인간에 대한 폭 넓은 이해가 필요함을 강조하였다. 월리엄 
세익스피어의 대표적인 4 대 비극과 5 대 희극에는 다양한 인물들 사이에 벌어지는 비극적 혹은 희극적 사연(life events)과 그 사연으로 유발된 감정(emotion)과 욕구(desire)가 매우 극적으로 소개된다. 결국 해리슨 내과학에서 제시한 인간 이해는 환자의 사연, 감정 그리고 욕구에 대하여 세심하게 이해하는 것이 의사에게 필요하다는 것을 강조한 것이다.

최근 췌장 및 담도 질환에 대한 여러 연구들에서 해리슨 내과학에서 제시한 인간 이해가 필요함을 시사하는 결과들이 적지 않게 보고되었다. 따라서 저자는 인간 이해의 측면에서 현재 췌장 및 담도 질환의 현황을 살펴보고, 췌장 및 담도 질환의 발병기전을 인간 이해의 측면에서 보다 근원적이고 전체적으로 추정하고, 또한 치료 효과를 보다 향상시키는 방안을 창출하기 위해 인간 이해가 필요함을 제안하고자 한다.

\section{배 경}

췌장 및 담도 질환의 진단 및 치료는 의학의 진보와 관련 술기 및 과학 장비의 발전으로 괄목한 성과를 이루었다. 하지만 다음과 같은 일부의 결과들은 현재 시행되는 고식적 치료에 대하여 인간 이해의 측면에서 검토가 필요함을 시사한다.

\section{1. 일부 담도 질환과 그와 연관된 질환의 증가}

국내 담낭 담석의 발생은 1961년부터 2005년까지 5년 단위로 관찰한 보고에서 꾸준히 증가하고 있으며, 최근 건강보험심사평가원에서 발표한 담낭 담석 환자 수는 2013년 92,440 명에서 2017년 112,761명으로 더욱 증가하였다. 담낭 담석의 진단이 증가한 일면에는 체계적으로 정비되고 국가적 혹은 개인적으로 운영되고 있는 건강검진의 역할도 있을 것이다. 하지만 음식이 서구화되면서 지방이 과량 섭취되고 자동차가 늘면서 개인 운동량이 줄어드는 등 생활양식의 변화와도 관련이 높다. ${ }^{4}$

담석 발생의 위험인자인 비만도 뚜렷하게 증가하였다. 비만은 담석 질환, 중증 급성 췌장염, 췌장암(pancreatic ductal adenocarcinoma) 발생과 연관되어 있다. ${ }^{5}$ 비만은 세계적으로 증가하고 있는 추세이며, 병적 비만증(morbid obesity)의 경우 2000 년과 비교하여 2010년 약 70\%가 증가하였다. 이러한 경향은 국내에서도 비슷하다. 2015년 19세 이상 성인에서 시행한 국민건강영양조사에서 비만율이 남성에서 $40 \%$, 여성에서 $26 \%$ 였는데, 이것은 1998 년의 남성 $25 \%$, 여성 $26 \%$ 와 비교하여 특히 남성에서 현저한 상승된 결과이다. ${ }^{6}$
향후 예상되는 2020년 및 2030년 비만 및 복부 비만의 유병률이 남성 $47 \%$ 및 $62 \%$, 여성 $32 \%$ 및 37\%로 전체적으로 상승하는 추세이다.

비만은 음식(칼로리) 과다 섭취 및 운동량 저하 등 개인 생활습관의 결과로 나타난다. 비만에 대하여 약물이나 수술 치료 등이 시행되고 있으나, 보다 근원적으로 치료 효과를 기대하려면 비만을 유발하는 생활습관을 꾸준히 지향하는 인간의 감정과 욕구에 대한 이해가 필요하다.

\section{2. 췌장 및 담도 질환과 환자의 사연 및 감정-욕구와의 연관성}

일부 췌장 및 담도 질환의 환자에게는 과거 혹은 현재 어떤 사연이 존재하며 동시에 그 사연과 관련된 감정과 욕구를 경험하였을 가능성이 높다. 오디괄약근 장애(sphincter of Oddi dysfunction, SOD) 및 자가면역 질환 환자는 어릴 때 신체적 혹은 성적 학대를 정상인과 비교하여 더 많이 겪었고, 질환 발현 당시에는 정상인과 비교하여 더 잦은 신체증상화 (somatization)와 함께 강박증, 우울증 등 감정의 어려움을 겪는 것으로 조사되었다. ${ }^{7-9}$ 췌장암과 우울, 불안, 만성 스트레스 등의 정신적 고통과의 연관성에 대한 연구 결과들도 꾸준히 보고되고 있다. ${ }^{10}$ 췌장암 환자의 $40 \%$ 는 정신적 고통을 호소하며, $30 \%$ 에서 임상적 우울증을 호소한다. ${ }^{11,12}$ 췌장암에서 우울증은 췌장암 진단으로 인한 결과일 수도 있지만, 췌장암 발병 전에 이미 우울증이 발현되어 있었다는 보고도 적지 않다. ${ }^{13-16}$

\section{3. 국내 자가면역 췌장 및 담도 질환의 증가}

최근 국내 췌장 및 담도 질환의 변화 중 주목할 만한 현상은 자가면역 질환의 증가이다. 국내 자가면역 췌장염(autoimmune pancreatitis, AIP) 및 담도염은 Kim 등 $^{17}$ 의 발표를 기점으로 현재까지 꾸준히 증가하고 있다. ${ }^{18,19} \mathrm{AIP}$ 는 조직에서 면역 관련 세포가 관찰되고, 혈액 검사에서 면역 관련 염증 세포 및 사이토카인 등이 증가하고, 스테로이드 치료에 뚜렷한 효과가 있다는 점 등으로부터 자가면역 질환의 특징을 갖고 있다. ${ }^{20}$ $\mathrm{AIP}$ 는 다른 자가면역 질환들과 유사하게 유전적 소인이 있는 환자에 환경적 위험인자가 가해지면서 발현된다고 추정된다. ${ }^{21}$ 환경적 위험인자에는 박테리아 감염, 산업환경물질 등이 있으며, 환경 변화에 대한 적응 반응인 스트레스도 그중 하나로서 이에 대하여 개입하기 위해서는 인간 이해가 요구된다. ${ }^{22}$ 


\section{4. 높은 질병 재발률}

제 1 형 AIP의 재발률은 약 24-60\%로 상당히 높으며, 추적 기간이 늘어나거나 스테로이드 유지 치료를 시행하지 않는 경우에 증가하는 양상이 관찰된다. ${ }^{18,23,24}$ 재발의 위험인자에는 다른 장기 침범(특히, 근위부 담도), 혈중 $\mathrm{IgG} 4$ 상승, 전반적 췌장 비대, 유전 요인 등이 있고, 재발에 대한 치료로는 스테로이드, 면역조절제 및 rituximab 등이 추천된다. ${ }^{21,25,26}$ 하지만 이처럼 재발률(약 $60 \%$ )이 높다는 것은 현재 통상적 으로 처방되는 약물 치료만으로는 장기간 호전이 지속되는 근원적 치료를 기대하기 어렵다는 의미일 수도 있다. 따라서 $\mathrm{AIP}$ 의 병리기전 중 조정하기 어려운 유전적 소인 이외에 조정이 가능할 수 있는 환경적 요소들에 대한 관심이 요구된다.

자가면역 질환인 원발성 담도경화증(primary biliary cirrhosis, $\mathrm{PBC}$ )의 주요 치료는 ursodeoxycholic acid이며, 간 손상이 진행되어 말기 간질환이 되었을 경우 최선의 치료는 간이식 이다. 그런데 간이식 후에도 재발률은 10년 후 21-37\%이고 15 년 후 $43 \%$ 에 달한다. ${ }^{27}$ 역시 유사한 병리기전으로 발병하는 원발성 경화성 담도염(primary sclerosing cholangitis, PSC) 에서도 간이식 치료 후 5-10년에서 20-25\%가 재발하여 PBC와 비슷한 결과가 관찰된다. ${ }^{28}$ 이러한 결과는 현재 $\mathrm{PBC}$ 및 $\mathrm{PSC}$ 의 치료로 시행되는 간이식 말고도 추가적 조치가 필요함을 의미한다. 또한 현재 명확하게 규정되지 못한 $\mathrm{AIP}, \mathrm{PBC}$, $\mathrm{PSC}$ 등 자가면역 질환의 발병기전에 대하여, 보다 광범위하고 근원적인 고찰이 필요하다는 것을 의미한다.

\section{인간 이해}

\section{1. 질병의 원인}

앞에서 현재 췌장 및 담도 질환에서 인간 이해의 측면에서 고려해야 될 내용이 소개되었다. 인간 이해는 환자의 사연, 감정 및 욕구 등에 대한 이해이며, 그러한 사연, 감정 및 욕구가 어떠한 과정을 거쳐 질병으로 이어지는 지에 대하여 추정해 볼 필요가 있다. 그렇게 하기 위해서는 1) 발병 요인, 2) 반복 자극을 가하는 인간의 습관 고리, 3) 인간이 태어날 때 이미 장착되어 있는 적응 반응에 대해 고려하는 것이 요구된다.

\section{1) 발병 요인}

췌장 및 담도를 포함한 인체는 근본적으로 물질(material) 이며, 물질로 이루어진 인체는 물질의 특성, 즉 물리적 특성을 절대로 벗어날 수 없다. 물질의 여러 특성 중 하나는 반복적
으로 가해지는 물리적 및 화학적 자극(stimulus)에 변형되고 손상된다는 것이다. 인간의 노화 및 그와 관련된 질환 그리고 자연사는 인간이 태어나서 물질로 이루어진 인체를 수십 년간 반복 사용하면서 물리적 및 화학적 자극으로 인하여 인체의 물질이 변형되고 손상된 결과이다.

유전적 요인 등으로 인하여 사람마다 차이가 있지만, 만성 질병이란 어떠한 이유로 비정상적 물리적 및 화학적 자극이 장기간 반복적으로 가해져 유발된 육체의 변화라고 할 수 있다. 그러므로 질병의 원인을 찾는 과정은 해당 장기에 반복적으로 자극을 가하는 물질이 무엇이며 또한 그러한 반복적 자극을 만드는 상황을 파악하는 것이다. 알코올성 췌장염은 알코올 이라는 화학 물질이 췌장을 반복적으로 자극하여 췌장이 변형되고 손상된 것이다. ${ }^{29}$ 선천성 질환인 췌담관합류이상 (pancreaticobiliary maljunction, PBM)에 병발하는 담도염, 담도암 및 담낭암은 췌장액이 담도 및 담낭으로 수십 년간 반복적으로 역류되면서 담도 점막에 반복적으로 가해진 화학적 물질의 자극에 따른 결과이다. ${ }^{30}$

\section{2) 인체에 반복 자극을 가하여 질병 유발하는 외부 또는 내부의 물질}

알코올성 췌장염의 병인인 알코올과 $\mathrm{PBC}$ 및 췌장암의 위험요소인 담배는 화학 물질인데, 인체 내부에서 만들어진 것이 아니라 외부에서 인체 내부로 유입된 것이다. ${ }^{29-34}$ 담낭 담석을 유발하는 지방식 및 췌장암의 위험인자인 비만을 유도하는 음식도 외부에서 인체로 유입된 것이다. ${ }^{4,535-37}$ 즉, 외부 물질이다. 이와는 반대로 PBM에서 담도염, 담도암 및 담낭암을 유발하는 췌장액은 췌장에서 정상적으로 생성되는 인체 내부의 화학 물질이다. ${ }^{30} \mathrm{SOD}$ 는 어떠한 원인으로 오디괄약근이 과도하게 수축되어 담즙 및 췌장액의 배출 장애 및 저류되면서 복통, 췌장염, 담도염 등이 발생하는 것이다. ${ }^{38,39}$ 이때 담즙 및 췌장액은 인체에서 정상적으로 생성되는 화학 물질이다.

질병을 유발하는 또 다른 자극물에는 어떤 원인으로 인체 내부에서 비정상적으로 과도하게 또는 새롭게 생성되는 면역 혹은 염증 세포 또는 사이토카인 등의 염증 유도 물질 등이 있다. $\mathrm{AIP}, \mathrm{PBC}$ 및 $\mathrm{PSC}$ 의 혈중 및 조직에서는 활성화된 $\mathrm{B}$ 또는 $\mathrm{T}$ 면역 세포, mitochondrial protein-expressing inflammatory cells 등의 염증 세포, IgG, IgG4, IgE 등의 면역글로불린, 항미토콘드리아항체(anti-mitochondrial antibody), 항중성 구세포질항체(anti-neutrophil cytoplasmic antibody) 등의 
자가면역항체, IL-6, IL-8 등의 염증 중개 물질, 결합조직 성장인자(connective tissue growth factor) 등의 전섬유화 중개 물질이 관찰된다. $20,21,28,31,32,40-42$ 앞에서 나열한 세포와 물질들은 어떠한 원인으로 인하여 비정상적으로 과도하게 생성되거나 또는 새롭게 만들어진 것이다. 췌장암 환자에서도 IL-6이 비정상적으로 증가되어 있는데, IL-6은 췌장암 환자에서 흔하게 동반된 우울증에서도 증가되어 있는 사이토카인 이라는 점에서 흥미롭다. ${ }^{43,44}$

\section{2. 외부 병인 물질의 반복적 유입과 내부 병인 물질의 과잉 혹은 새로운 생성의 원인}

앞에서 열거한 외부 또는 내부 병인 물질의 반복 자극에 의하여 췌장 및 담도 질환이 발생한다면, 인간 이해의 측면 에서 다음과 같은 질문이 제기된다. 그렇다면 왜 술, 담배, 지방식 등의 해로운 외부 물질을 인체 내로 반복적으로 유입하는 이유는 무엇일까? 그리고 인체 내부에서 면역 혹은 염증 세포 또는 사이토카인 등의 염증 유도 물질이 비정상적으로 과도 하게 또는 새롭게 생성되는 이유는 무엇인가? 그와 같이 외부 병인 물질을 반복적으로 인체 내로 유입하는 이유는 일정한 행동을 은연 중 반복하면서 형성된 습관 고리(habit loop) 때문이다. ${ }^{45}$ 습관 고리는 개인의 선호도에 따라 의식적으로 결정된 행동의 만족 경험이 장기간 반복되면서, 종국에는 동일한 상황을 마주하면 자동적으로 반응하는 행동 시스템 으로 고착화된 것이다.

인체 내부에서 면역 혹은 염증 세포 또는 사이토카인 등의 염증 유도 물질이 비정상적으로 과도하게 또는 새롭게 생성 되는 원인은 다양하다. 그중 일부분은 환경 변화에 본인이 의식하지 못하는 사이 자동적으로 진행되는 '적응 반응 (adaptive response)' 때문으로 추정된다. ${ }^{46-50}$ 모든 인간의 내부에는 환경의 변화에 적응하여 생존하는데 필요한 반응 시스템이 이미 태어날 때부터 탑재되어 있다. 그리고 그 시스템은 환경 변화에 대하여 즉각적이고 무의식적으로 그리고 급속하게 진행된다.

\section{1) 습관 고리}

환자가 질병을 초래하는 특정 행동을 무의식적으로 반복 하는 이유는 '습관 고리'의 행동패턴 때문이다. 사람이 어떤 상황(신호)을 마주하면 의식적으로 결정된 행동(반복 행동)을 수행하고, 사람은 그 수행을 통하여 만족감(보상)을 얻는다. 그리고는 일상생활 중 이전 상황(신호)과 비슷한 상황을
마주할 때마다 매번 동일한 과정을 반복하고, 그러한 기간이 어느 정도 이상 지속되면 종국에는 '신호 $(\mathrm{cue}) \rightarrow$ 반복 행동 (routine act) $\rightarrow$ 보상(reward)'의 3단계로 구성된 습관 고리를 형성한다. ${ }^{45}$

기존에 제시된 3단계 습관 고리(three-step habit loop)에서 한 단계 더 나아가 인간의 무의식적 반복 행동을 좀 더 명확히 이해하기 위하여서는, 내관(內觀, introspection)을 통한 인간의 감정과 욕구에 대한 통찰이 필요하다. 심리학자 폴 에크만 (Paul Ekman)의 자문으로 제작된 영화 '인사이드 아웃 (inside out)'에는, 인간의 행동이 인간 내부에서 발생한 다섯 가지 감정(기쁨, 슬픔, 버럭, 소심, 까칠)과 욕구에 따라 취해진 결과라는 것이 잘 형상화되어 있다. ${ }^{51}$ 다시 말하여 인간에게는 매 상황마다 어떤 결정과 행동을 취하기 전 '감정'과 '욕구'가 발생한다. 즉, 기존의 3단계 습관 고리의 출발점인 신호와 반복 행동 사이에 '감정'과 '욕구'가 유발되어 개입한다. 이에 3단계 습관 고리에 유발된 '감정'과 '욕구'의 한 단계를 추가한 4단계(four-step habit loop)를 통하여 사람의 무의식적 반복 행동을 보다 더 명확하게 이해할 수 있으며 그 과정은 다음과 같다(Fig. 1): 신호(cue) $\rightarrow$ 감정(emotion)과 욕구(desire) $\rightarrow$ 반복행동(routine act) $\rightarrow$ 보상 $($ reward).

4 단계 습관 고리에 연결되어 곧바로 진행되는 과정은 '적응 반응'이다. 4 단계 습관 고리의 '신호'에 의하여 유발된 '감정'과 '욕구'는 뇌에서는 항상성(homeostasis)을 위협하는 환경 변화, 즉 스트레스(stress)로 인지된다. ${ }^{46-50}$ 그리하여 환경 변화에 적응하는 반응(행동)으로 지체 없이 이어지는데, 그 반응

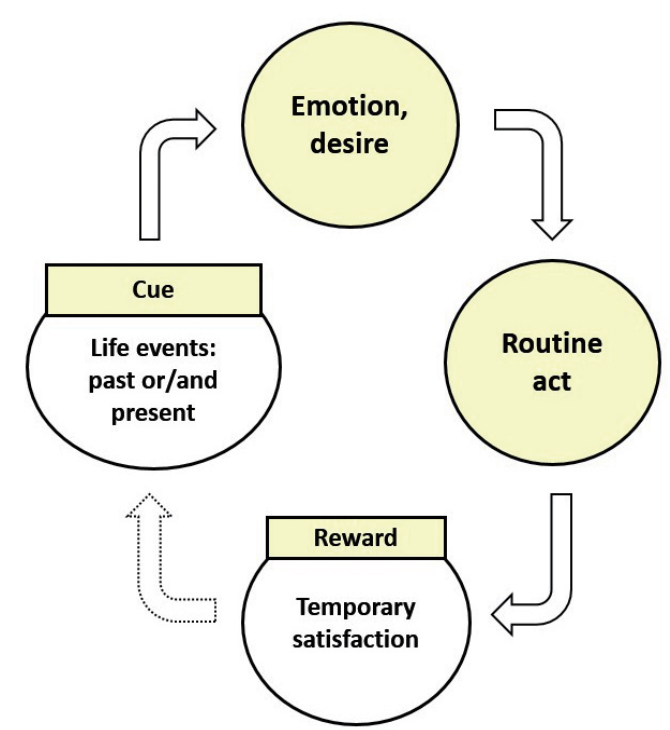

Fig. 1. Four-step habit loop. 
(행동)은 다음의 2 가지 과정으로 진행된다. 하나는 발생한 감정과 욕구를 외부(exterior)로 발산하는 것으로 외부 물질을 체내로 유입하는 것이고(외부 적응 반응), 다른 하나는 인체 내부(interior)로 진행되는 반응으로 내분비계 및 자율신경계를 통한 반응이다(내부 적응 반응).

\section{2) 적응 반응}

\section{(1) 외부 적응 반응}

습관 고리의 신호로 유발된 감정과 욕구를 해결하기 위하여 외부적인 수단, 즉 외부 물질을 체내로 유입하는 과정이다. 알코올성 췌장염의 원인은 알코올인데, 알코올은 인체에서 만든 것이 아니라 외부에서 인체 내로 유입된 물질이다. 예를 들면 알코올이 인체 내로 유입되는 과정은 다음과 같다. 회사 상사로부터 꾸지람을 듣거나 혹은 대한민국 축구팀이 승리 하였다는 소식(신호)에, 갑자기 우울해지거나 화나거나 혹은 기쁨이 발생한다(감정). 그리고는 동시에 우울, 화 혹은 기쁨을 해소하기 위하여 술을 마셔야겠다는 '욕구'가 유발된다. 그리고는 냉장고 문을 열고 비치되어 있던 술을 끄집어 내어 혹은 마켓으로 달려가 술을 구입하여 마신다(반복 행동). 그리고는 음주 후 느껴지는 취기와 포만감에서 신호로 유발 되었던 감정 및 욕구가 해결되는 만족감(보상)을 얻는다. 전체적으로 알코올성 췌장염 환자의 4 단계 습관 고리는 다음과 같다: 회사 상사의 꾸지람 혹은 대한민국 축구팀의 승리 소식(신호) $\rightarrow$ 유발된 감정(우울, 화, 기쁨)과 (음주) 욕구 $\rightarrow$ 음주 실행(반복 행동) $\rightarrow$ 취기와 포만 후 만족감(보상).

\section{(2) 내부 적응 반응}

습관 고리의 신호로 유발된 감정과 욕구를 해결하기 위한 또 다른 하나의 적응 반응은 인체 내부 적응 시스템의 활성화 이다. 인체 내부에는 환경 변화에 적응하기 위한 반응 시스템이 태생 때부터 이미 장착되어 있다. 일종의 생존 시스템으로 감정 및 욕구에 대한 반응으로 무의식적이며 자동으로 작동 되는 내분비계와 자율신경계이다(Fig. 2). 내분비계의 자극은 시상하부-뇌하수체-부신피질 축(hypothalamus-pituitaryadrenal cortex [HPA] axis)이 활성화되어, 시상하부에서 부신피질자극호르몬 유리인자(corticotropin releasing factor, $\mathrm{CRF}$ ), 뇌하수체에서 부신피질자극호르몬(adrenocorticotropic hormone, ACTH)이 분비되고 최종적으로 부신 피질(adrenal cortex)이 자극되어 글루코코티코이드(glucocorticoid)가 분비된다.

자율신경계의 자극은 뇌교(pons)와 척수를 경유하여 교감신경(sympathetic nerve)에 전달되고, 최종적으로 말단 교감신경 및 부신 수질(adrenal medulla)을 자극하여 노르에 피네프린(norepinephrine, NE)과 에피네프린(epinephrine, $\mathrm{EP})$ 을 분비시킨다. 또한 항진된 교감신경의 자극은 췌장, 담도 및 오디 괄약근(sphincter of Oddi)에 분포된 자율신경 에도 전달된다. ${ }^{52}$

면역 세포에는 자율신경계의 신경전달물질과 내분비계의 호르몬에 대한 수용체가 존재하여, 항상성을 유지하기 위하여 작동된 $\mathrm{HPA}$ 축과 교감신경의 항진으로 분비되는 여러 호르몬 (CRF, ACTH, glucocorticoid 등), 카테콜아민(NE, EP), 뉴로펩타이드 등에 반응하고 활성화된다. 활성화된 단핵구, 림프구, 대식 세포 등은 IL 혹은 TNF 등의 염증 유도 물질을 분비하여, 각종 염증 반응을 유도 및 악화시키고 면역 반응을 과도 항진 혹은 억압시킨다.

\section{(3) 외부 및 내부 적응 반응에 의한 인체 변화}

첫 번째 적응 반응인 외부로의 반응으로 초래되는 인체의 변화는 병인 물질의 체내 유입에 따른 변화이다. 알코올성 췌장염을 일으키는 알코올, 콜레스테롤 담석증을 초래하는 지방 음식 등이 인체 내로 유입된다. 반복적으로 섭취된 알코올 혹은 지방 음식은 체내에 과도하게 축적되어 혹은 직접적으로 조직에 손상을 입혀 질병을 유발한다.

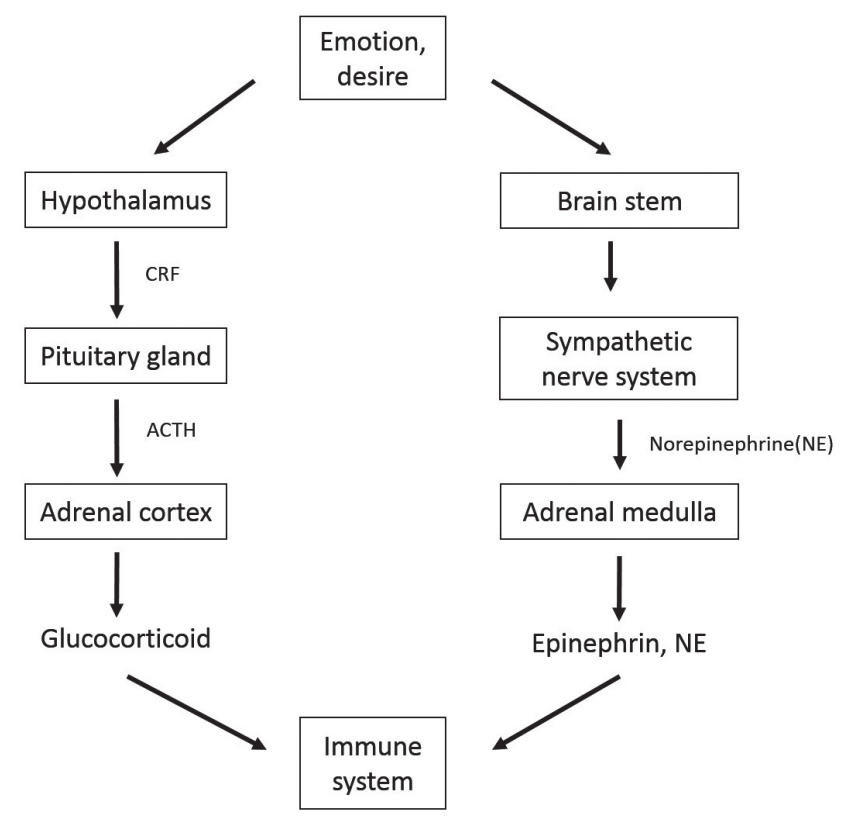

Fig. 2. Adaptive response of HPA axis and sympathetic nervous system activated by emotion and desire. CRF, corticotropin-releasing factor; ACTH, adrenocorticotropic hormone; HPA, hypothalamus-pituitaryadrenal cortex. 
두 번째 적응 반응인 내부로의 반응은 HPA 축과 교감신경계의 활성화이다. ${ }^{46-50} \mathrm{HPA}$ 축의 활성화로 $\mathrm{CRF}, \mathrm{ACTH}$ 및 글루코코티코이드가 분비되고, 교감신경계가 항진되어 $\mathrm{NE}$ 및 $\mathrm{EP}$ 이 분비된다. $\mathrm{HPA}$ 축 및 교감신경에서 분비된 글루코 코티코이드, $\mathrm{NE}, \mathrm{EP}$ 등은 면역계에 작용하여 면역계 기능의 이상 및 억제를 초래한다. 그와 같은 과정에 면역 세포가 과도하게 항진되거나 또는 억제되며, 여러 가지 염증 매개물질 및 사이토카인이 과도하게 혹은 새롭게 생성된다. 또한 췌장 및 담도에 분포된 자율신경계의 교감신경이 항진되면서, 평활근(smooth muscle)으로 이루어진 담낭과 오디 괄약근을 자극한다. 그리하여 담낭의 수축 기능이 저하되고 오디 괄약근은 과도하게 수축되어, 종국에는 담즙 및 췌장액의 배출이 원활해지지 못하고 담낭, 담도 및 췌관에 정체 된다. ${ }^{4,38,39}$

\section{3. 췌장 및 담도 질환 환자에서 관찰되는 사연(life event: 과거 기억 및 현재 상황)과 유발된 감정 (emotion) 및 욕구(desire)}

파블로프의 조건반사(conditioned reflex)는 학습된 기억은 언제든지 현재의 시점으로 불러내 똑같이 재현될 수 있으며 또한 인체 내부에서는 그에 상응하는 생리학적 변화와 함께 물질을 만들어 낼 수 있다는 것을 증명하였다. ${ }^{53}$ 즉, 구체적 형체가 없는 기억만으로도 구체적 형체가 있는 물질을 만들어 낸다. 기억은 어떤 특정 사연과 그 사연으로 유발된 감정 및 욕구 등을 모두 포함한다.

췌장 및 담도 환자에게 4 단계 습관 고리를 적용하면, 4 단계 습관 고리의 시작인 신호(cue)는 환자에게는 '개인 사연(life events)'에 해당된다. 인간 삶 중 일어나는 다양한 사연과 그 사건으로 유발되는 감정과 욕구는, 과거 기억이든 현재 닥친 상황이든 고통스러운 것이든 기쁜 것이든 당사자에게 감정적 충격을 준다.

Table 1. Social Readjustment Rating Scale ${ }^{54}$

\begin{tabular}{|c|c|c|c|c|c|}
\hline Rank & Life event & Mean value & Rank & Life event & Mean value \\
\hline 1 & Death of spouse & 100 & 23 & Son or daughter leaving home & 29 \\
\hline 2 & Divorce & 73 & 24 & Trouble with in-laws & 29 \\
\hline 3 & Marital separation & 65 & 25 & Outstanding personal achievement & 28 \\
\hline 4 & Jail term & 63 & 26 & Wife begin or stop work & 26 \\
\hline 5 & Death of close family member & 63 & 27 & Begin or end school & 26 \\
\hline 6 & Personal injury or illness & 53 & 28 & Change in living conditions & 25 \\
\hline 7 & Marriage & 50 & 29 & Revision of personal habits & 24 \\
\hline 8 & Fired at work & 47 & 30 & Trouble with boss & 23 \\
\hline 9 & Marital reconciliation & 45 & 31 & Change in work hours or conditions & 20 \\
\hline 10 & Retirement & 45 & 32 & Change in residence & 20 \\
\hline 11 & Change in health of family member & 44 & 33 & Change in schools & 20 \\
\hline 12 & Pregnancy & 40 & 34 & Change in recreation & 19 \\
\hline 13 & Sex difficulties & 39 & 35 & Change in church activities & 19 \\
\hline 14 & Gain of new family member & 39 & 36 & Change in social activities & 18 \\
\hline 15 & Business readjustment & 39 & 37 & Mortgage or loan of less than $\$ 10,000$ & 17 \\
\hline 16 & Change in financial state & 38 & 38 & Change in sleeping habits & 16 \\
\hline 17 & Death of close friend & 37 & 39 & Change in number of family get-togethers & 15 \\
\hline 18 & Change to a different line of work & 36 & 40 & Change in eating habits & 15 \\
\hline 19 & Change in number of arguments with spouse & 35 & 41 & Vacation & 13 \\
\hline 20 & Mortgage over $\$ 10,000$ & 31 & 42 & Christmas & 12 \\
\hline 21 & Foreclosure of mortgage or loan & 30 & 43 & Minor violations of the law & 11 \\
\hline 22 & Change in responsibilities at work & 29 & & & \\
\hline
\end{tabular}


Holmes와 Rahe ${ }^{54}$ 은 '인간이 삶에서 겪는 사연과 그 사연에서 느껴지는 감정적 충격의 정도'를 객관적으로 측정한 목록을 발표하였다(Table 1). 사연의 목록은 배우자의 죽음에서부터 사소한 법규의 위반까지 43 개로 분류하고, 각각의 사연에 대한 감정적 충격의 정도를 객관적으로 가늠한 수치를 제시하였다. 물론 43 개의 사안이 인간이 살면서 경험하는 모든 사연을 포함하지는 못하였다. 하지만 Table 1 에서 알 수 있는 것은 자존과 생존에 의미 있는 사연은 과거 사연이든 현재 사연이든 당사자에게 감정적 충격을 준다는 점이다. 더 나아가 고통 스럽고 강렬한 감정을 동반한 자존과 생존에 관련된 경험의 기억은 '운동분열(schizokinesis)'을 유발하며, 마치 유전적 으로 확고한 틀이 정해진 것처럼 작동하여 삶 중 비슷한 상황을 마주하면 언제든지 현재 시점으로 재현되고 또한 그에 따른 생리적 변화를 초래한다. ${ }^{55,56}$

인간 삶 중 마주한 Table 1과 같은 사연은 당사자에게 감정을 유발하고, 그 감정은 변화와 적응에 대한 욕구를 유발한다. 즉, 4 단계 습관 고리를 가동시킨다. 췌장 및 담도 질환 환자에서 습관 고리를 가동시키는 과거 기억 및 현재 상황에 관련된 다양한 사연과 그 사연에 따라 유발된 감정이 관찰된다.

\section{1) 어린 시절 경험}

부정적인 생애 초기 경험과 인생사의 스트레스(life stress)가 우울증의 위험 요인으로 작동한다는 것이 익히 알려져 있다. ${ }^{57-59}$ 비만은 담낭 담석의 위험인자인데, 어린 시절 정신적 혹은 신체적 학대의 스트레스와 관련이 높다. ${ }^{60,61}$ 어린 시절 스트레스는 호르몬 및 뇌 이상과 연관이 있으며, 이는 에너지 섭취 과다 및 에너지 소비 저하로 이어지면서 비만으로 발전 한다. SOD 및 자가면역 질환의 환자에서 어릴 때 신체적 혹은 성적 학대를 정상인과 비교하여 더 많이 겪었고, 질환 발현 당시에는 정상인과 비교하여 더 잦은 신체 증상화(somatization)와 함께 강박증, 우울증 등 감정의 고통을 겪는다. ${ }^{7-9}$ 암 환자에서도 유년시절에 비슷한 경험을 겪는다. ${ }^{62}$ 어린 시절 곤란하고 위험하고 긴장 가득한 인간관계 속에서 생활하면서 고립, 무시 그리고 절망의 감정을 매우 강렬하게 경험한다.

\section{2) 음주, 흡연 및 비만과 우울}

음주는 알코올성 췌장염의 위험인자이고, 담배는 췌장염, $\mathrm{PBC}$ 및 췌장암의 위험인자이며, 비만은 담석 질환과 중증 급성 췌장염의 발생과 연관성이 높으며 췌장암 발생의 위험을 증가시킨다.5,31-34 이와 같이 여러 췌장 및 담도 질환에 위험인자인 음주, 흡연 및 비만은 모두 우울증과 관련이 있다. 알코올성

췌장염의 가장 흔한 유발 요인인 알코올 사용 장애와 우울증의 동반 이환율은 약 $30 \%$ 에 달하며, 알코올 사용 장애와 우울증은 서로에게 원인이자 결과로서 쌍방향으로 작용 한다. ${ }^{63}$ 췌장염, $\mathrm{PBC}$ 및 췌장암의 위험인자인 흡연이 정상인과 비교하여 우울증에서 2 배 가량 높다. ${ }^{64,65}$ 과체중 또는 비만과 정상 체중을 메타분석한 보고에서 우울증이 과체중 혹은 비만에서 $32 \%$ 더 많았고 이러한 경향은 특히 여성에게 두드러 졌다. ${ }^{66}$

\section{3) 스트레스와 자가면역 질환}

외상 후 스트레스 장애 및 공황 장애 환자에서 자율신경계 조절장애(autonomic dysregulation)로 교감신경계가 항진되며, 면역체계에 영향을 받아 질병에 취약해지는 것은 잘 알려져 있는 사실이다. ${ }^{67,68}$ 최근 국가 단위의 대규모 코호트 연구에서 스트레스 연관 질환에의 노출이 $\mathrm{PBC}$ 를 포함한 자가면역 질환의 위험을 올리는 사실이 보고되었다. ${ }^{69}$

자가면역 췌장염에서 10 갑년 이상의 흡연이 전산화단층 촬영이나 자기공명영상검사에서 확인되는 췌장 손상과 당뇨 발생의 위험인자가 된다. ${ }^{70}$ 또한 하루 $50 \mathrm{~g}$ 이상의 음주는 췌관 결석과 췌장 위축의 위험을 높인다. ${ }^{71} \mathrm{PBC}$ 의 경우 특징적인 증상으로 피로감이 있는데 이는 우울증과 서로 연관이 있다. ${ }^{72}$ 흡연이 $\mathrm{PBC}$ 발병의 중요한 위험인자이며 간경화 진행의 위험인자가 된다. ${ }^{73}$ 또한 $\mathrm{PBC}$ 환자에 대하여 항우울제의 사용이 생존율 및 예후에 좋은 영향을 주는 최근 연구 결과가 있다. ${ }^{74}$

\section{4) 췌장암과 우울}

췌장암과 우울증 간의 관련성은 오래 전부터 관심 주제였다. 췌장암 환자에서 (정신적) 고통(distress), 우울과 불안의 정도가 상대적으로 높으며, 췌장암 환자 가운데 The Zung self-rating depression scale 점수가 50점 이상인 우울증 의심군이 $50 \%$ 가량을 차지하여 췌장암 환자의 상당수가 우울 증상을 동반하고 있다. ${ }^{11,12,75,76}$

췌장암 환자에서 우울증 발현의 시기에 대한 보고에서 대 부분은 췌장암 진단 후 이차적으로 우울증이 발현되었다는 보고가 많다. 하지만 일부 보고에서는 췌장암 환자의 우울증이 췌장암 진단에 따른 이차적으로 발생하였다기보다는 췌장암 발현 전 이미 선행하고 있었을 가능성에 대한 결과가 꾸준히 보고되고 있다. ${ }^{13-16}$ 


\section{4. 췌장 및 담도 질환 환자에서 관찰되는 HPA 축 및 교 감신경의 활성화(혹은 적응 반응)의 소견}

1) 병인(염증) 물질과 염증 세포

췌장 및 담도 질환에서 염증 혹은 면역 반응을 유발, 저지 혹은 악화시키는 다양한 사이토카인이 관찰된다. AIP의 조직에서는 Th1 및 Th2 사이토카인이 모두 풍부하게 관찰 되는데, B 세포를 활성화시켜 IgG4를 분비시키는 IL-4, IL-10, IL-21 등이 증가하며, 호중백혈구를 활성화시키는 IL-4, IL-5, IL-13 등이 증가하고, 섬유모 세포를 활성화시키는 TGF- $\beta$ 도 증가한다. ${ }^{21}$ 이에 호중백혈구와 섬유모 세포가 활성화되고, 이외에도 호염기백혈구, 단핵구, 대식 세포 등이 활성화되며 보체가 감소한다.

$\mathrm{PBC}$ 에서는 염증 세포가 담관상피세포층과 문맥관 그리고 손상된 담도 주변에 침윤된다. 이 염증 세포의 침윤은 $\mathrm{PBC}$ 의 초창기에 뚜렷하며, 염증 세포는 $\mathrm{CD} 68+$ 단핵구, $\mathrm{MPO}+$ 단핵구, 대식 세포나 $\mathrm{CD} 38+, \mathrm{CD} 79 \mathrm{a}+, \mathrm{CD} 138+, \mathrm{IgM}+$ 또는 $\mathrm{IgG}+$ 형질 세포 등이다. ${ }^{42}$

췌장암과 IL-6의 관련성에 대한 보고에서, IL-6는 스트레스성 면역억제의 중개물질이며 췌장암 및 우울증의 발병에 중요 하다. ${ }^{.79}$ 또한 IL-6는 종양 세포 stemness의 유도 등 종양발생과 전이에 관여하며, 췌장암 환자의 생존에도 관련이 있다. ${ }^{80-82}$ 췌장암 환자에서 우울증이 많으며, 우울증 환자에서는 염증촉진
사이토카인(IL-6, TNF- $\alpha$, TNF- $\beta 1, \mathrm{INF}$ ) 및 C-반응성 단백질 (C-reactive protein)이 증가한다. ${ }^{11-14,44}$

\section{2) 면역 이상 반응}

$\mathrm{AIP}$ 에서 $\operatorname{IgG} 4$ 가 대량으로 관찰되고, 혈중에서 면역체계의 조절장애(dysregulation)로 생산되는 비정상적 자가항체가 관찰된다. 자가항체는 일차적 혹은 이차적 반응인지 명확하지 않지만, 항핵항체, 항carboanhydrase II 항체, 항평활근항체, 항인락토페린항체, 류마티스인자, 췌장분비트립신억제제 (pancreatic secretory trypsin inhibitor), 트립시노겐 PRSS1과 PRSS2에 대한 자가항체 등 다양한 자가항체가 혈중에서 관찰된다. ${ }^{20,21,83}$

$\mathrm{AIP}$ 의 혈중 및 조직에서 면역 세포의 변화가 관찰된다. 혈중에서 T-세포의 Th1/Th2 균형이 변하고, 여러 종류의 조절 $\mathrm{T}$ 세포(Tregs)와 조절 $\mathrm{B}$ 세포(Bregs)가 증가 혹은 감소되어 있다. ${ }^{21,84,85}$ 췌장조직에서 1형 AIP에서는 IgG4-생산 형질세포, $\mathrm{B}$-림프구 항원 $\mathrm{CD} 20$ 이, 2형 $\mathrm{AIP}$ 에서는 $\mathrm{CD}$ 4-양성 $\mathrm{T}$ 세포와 과립구가 관찰된다. ${ }^{25}$

$\mathrm{PBC}$ 환자의 혈중에서 특징적 자가항체인 항미토콘드리아 항체가 90-95\%에서 발견되며, 그 이외에도 항핵항체와 항평 활근항체가 약 $50 \%$ 의 환자에서 관찰된다. ${ }^{86}$ 간 조직에서는 자가반응 CD4 PDC- 및 CD8 PDC- E2-특이 T 세포가 혈액 보다 각각 100-150배, 10-15배 더 많이 관찰된다. ${ }^{32}$

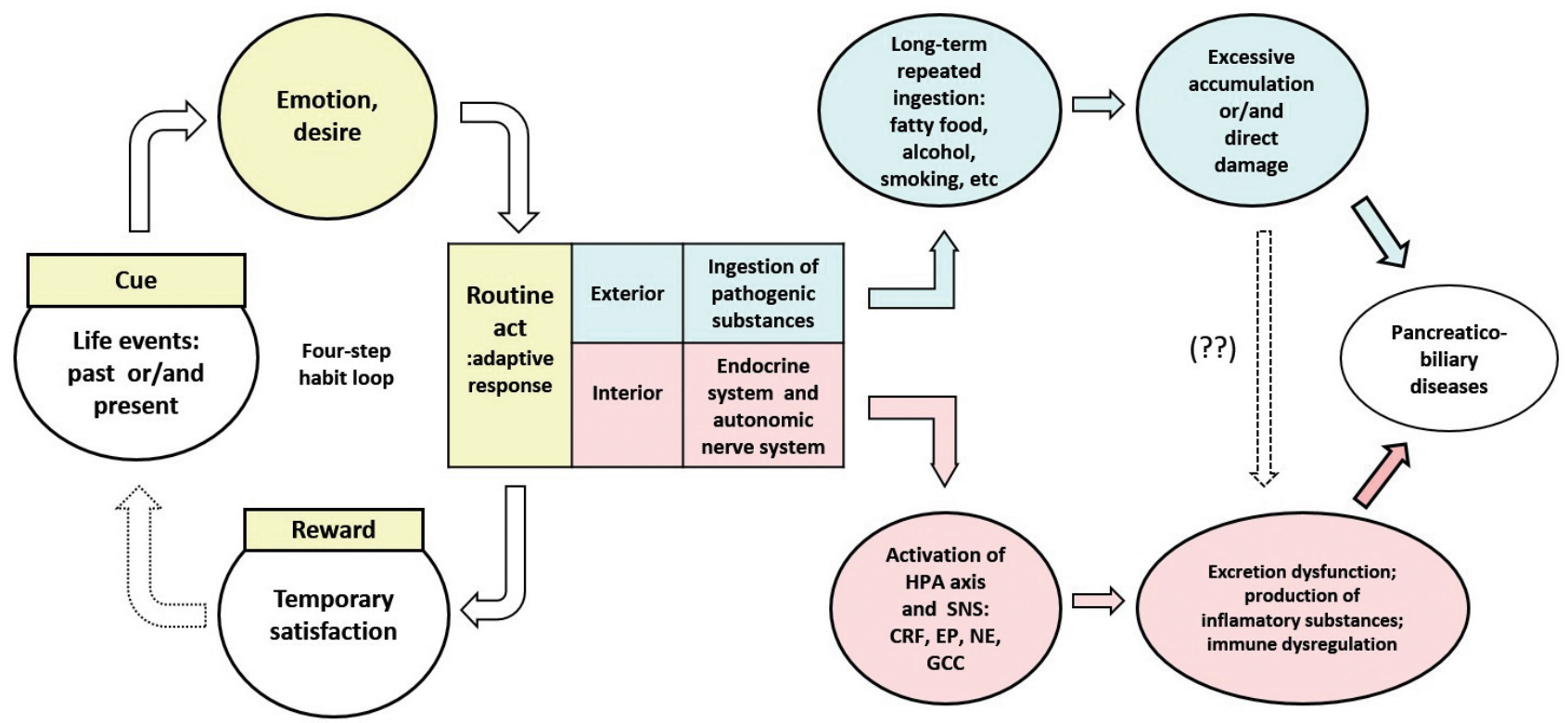

Fig. 3. The model for the development of pancreaticobiliary disease considering human understanding. HPA, hypothalamus-pituitary-adrenal cortex; SNS, sympathetic nerve system; CRF, corticotropin-releasing factor; EP, epinephrine; NE, norepinephrine; GCC, glucocorticoid. 
$\mathrm{PSC}$ 의 혈액에서도 다양한 자가항체가 관찰되는데, 항중성구세포질항체, 항핵항체, 항평활근항체, 항내피세포항체 (anti-endothelial cell antibody), 항카디오리핀항체(anticardiolipin antibody), 류마티스인자 등이다. ${ }^{28,87} \mathrm{PSC}$ 의 담도 병변에 주로 활성화된 작동(effector) 또는 기억(memory) $\mathrm{T}$ 세포의 침윤이 관찰되고, 그 외에 $\mathrm{B}$ 세포, 자연살해 $\mathrm{T}$ 세포 (NK T cell), 대식 세포 등도 관찰된다. ${ }^{88}$

\section{3) 췌장암에서 stress-induced $\beta$-adrenergic signaling}

췌장암 세포에는 $\beta 1$-과 $\beta 2$-아드레날린성 수용체가 존재 하여, $\mathrm{NE}$ 과 $\mathrm{EP}$ 에 의한 $\beta$-아드레날린 자극에 영향을 받는다. ${ }^{10}$ 심리적 고통(psychological distress)의 $\beta$-adrenergic signaling을 통한 췌장암 진행(progression)에 대한 체외 및 체내 실험 연구의 흥미로운 결과가 보고되었다. Chan 등 ${ }^{89}$ 은 NE의 인간췌관 세포(human pancreatic duct cell)에 대한 성장촉진 효과를 알아보기 위한 체외 실험을 진행하였다. 비록 암세포가 아니고 양성 췌관 상피세포(benign duct epithelial cell)에서 진행되었지만, $\mathrm{NE}$ 군에서 대조군에 비교하여 세포증식이 2.5 배 증가하였고, IL-6 생성에 유의한 변화를 유도하였다. Schuller 등 ${ }^{90}$ 은 인간 췌장암 세포계(human PC cell lines)를 피하 주사한 6주된 누드마우스에 일정 기간 심리적 스트레스 후 종괴 크기와 $\beta$-adrenergic pathway 관련 물질을 측정하였다. 그 결과 4주간 스트레스에 노출된 쥐에서 종괴 크기가 2-4배 이상 커졌으며, 전신 및 종괴 내 $\beta$-adrenergic pathway 관련 물질도 상승하였다. Shan 등믄 췌장암 세포계를 주입한 생쥐들에 음향 및 육체적 스트레스를 가한 후 종괴 크기, Ki-67 표현, 종양 혈관생성인자들(VEGF, MMP-2, MMP-9)을 측정하였다. 결과는 만성 스트레스를 받은 생쥐에서 종괴 크기, Ki-67로 측정한 유사분열률(mitotic rate), 종양 혈관생성 인자들이 모두 유의하게 상승하였다. Kim-Fuchs 등 $^{77}$ 은 인간 췌장암 세포계를 쥐의 췌장 미부에 직접 접종하고 육체적 제약 스트레스를 가한 후 변화를 관찰하였다. 결과는 종괴 크기가 5 배 증가하고, 국소 침범이 유의하게 높았으며, 원격 전이가 $50 \%$ 에서 관찰되었다. 다만 앞서 기술한 여러 연구들에서 카테콜라민과 그 대사물에 대한 동반 검사가 진행되지 않아, $\beta$-아드레날린성 자극이 췌장암 발생에 직접적으로 작용하 였다고 단언하기는 어렵다. ${ }^{10}$ 하지만 심리적 고통이 췌장암 발병에 중요한 한 요인으로 작용할 가능성을 제기하여, 후속 연구들을 통하여 입증될 것으로 기대된다.

\section{인간 이해를 고려한 췌장 및 담도 질환 발병 모델}

Fig. 3는 앞에서 기술한 인간 이해 1-4를 종합하여 추정한 췌장 및 담도 질환의 발병 모델이다. 과거 기억 혹은 현재 상황의 어떤 사연이 '신호'가 되어 4단계 습관 고리가 작동된다. 그 신호에 의하여 '감정'과 '욕구'가 유발되고 그 감정과 욕구를 해결하기 위하여 '반복 행동(적응 반응)'을 취한다. 그 행동 (적응 반응)을 통하여 신호로 유발되었던 감정과 욕구가 해결되면서 일시적 만족감으로 '보상'을 얻는다. 환자는 일상 생활 중 '사연'을 마주할 때마다 4 단계 습관 고리를 꾸준히 반복한다.

4 단계 습관 고리의 '반복 행동(적응 반응)'은 곧바로 다음 2 가지로 이어진다. 하나는 외부에서 병인 물질을 체내로 반복적 유입하며, 병인 물질이 과잉 축적되어 혹은 장기에 직접 손상을 일으킨다. 다른 하나는 내분비계와 자율신경계를 통한 적응 반응이다. 내분비계의 HPA 축이 활성화되면서 $\mathrm{CRF}, \mathrm{ACTH}$ 및 글루코코티코이드가 분비되고, 자율신경계의 교감신경이 항진되면서 $\mathrm{NE}$ 및 $\mathrm{EP}$ 이 분비된다. $\mathrm{HPA}$ 축의 글루코코티코이드와 교감신경의 $\mathrm{NE}$ 및 $\mathrm{EP}$ 은 종국에는 면역계 기능의 이상 혹은 억제를 초래한다. 또한 교감신경의 항진은 췌장 및 담도의 평활근에 직접 작용하여 담즙 및 췌장액의 배출 기능을 저하시킨다.

간략히 정리하면 사연(신호)으로 유도된 감정과 욕구에 대한 적응 반응으로 병인 물질의 체내 유입과 $\mathrm{HPA}$ 축 및 교감신경의 활성화가 되고, 그러한 적응 반응이 장기간 반복 및 지속되면서 췌장 및 담도에 가해지는 화학적 및 물리적 자극이 오랫동안 되풀이되어, 종국에는 췌장 및 담도가 손상되고 질병이 발생 한다.

\section{결 론}

해리슨 내과학 첫 페이지에 기술된 의사에게 요구되는 '인간 이해'는, 질병은 단순히 물질만의 문제는 아니라는 뜻이기도 하다. 그러한 질병이 발생하기까지 환자의 삶에서 벌어졌던 사연과 그 사연과 관련되어 환자가 경험한 감정과 욕구에 대한 관심과 치유가 필요하다는 의미이다. 더 나아가 인간이 무의식적으로 반복 행동을 취하는 습관 고리와 태어날 때부터 이미 장착된 적응 반응 시스템에 대한 통찰이 필요 하다는 뜻이다.

췌장 및 담도 질환에서 현재 시행되는 고식적 치료의 효과를 
더욱 향상시키고, 치료 후 재발률을 줄이고, 더 나아가 근원적 으로 췌장 및 담도 질환의 발병을 줄이고 또한 예방하려면, 습관 고리와 환경 변화 적응 반응이 무의식으로 작동하는 인간에 대한 총체적 이해를 추가한 발병기전에 대한 숙고가 필요하다. 이에 본 논문에서는 환자의 사연이 질병으로 발전 하는 과정을 추정하여 설정한 '인간 이해를 고려한 췌장 및 담도 질환 발병 모델'을 제시한다.

\section{요 약}

해리슨 내과학에 의사에게 요구되는 세 가지 덕목 중 하나로 인간 이해를 소개하면서, 진정한 의사에게는 'Shakespearean breadth'가 필요하다고 강조하였다. 최근 췌장 및 담도 질환 에서는 담낭 담석의 지속적 증가, 환자의 사연과 췌장-담도 질환과의 연관성, 자가면역 질환의 증가, 치료 후 높은 재발률 등 인간 이해가 요구되는 보고가 늘어났다. 이에 췌장 및 담도 질환의 발병기전을 인간의 습관 고리 및 적응 반응까지도 포함한 전체적이고 근원적으로 파악하여, '인간 이해를 고려한 췌장 및 담도 질환의 발병 모델'을 제시한다.

국문 색인: 췌장 및 담도 질환, 인간 이해, 습관 고리, 적응 반응

\section{Conflicts of Interest}

The authors have no conflicts to disclose.

\section{REFERENCES}

1. Kasper D, Fauci A, Hauser S, Longo J, Jameson J, Loscalzo J. Harrison's principles of internal medicine. 19th ed. p1, New York, McGrawHill Companies, 2015.

2. Fauci AS, Braunwald $E$, Isselbacher KJ, et al. Harrison's principles of internal medicine. 14th ed. p1, New York, McGraw-Hill Companies, 1998.

3. Yang SH, Lee SE, Jang JY, et al. Clinical and epidemiological analysis of gallstone patients focused on 25-year experience of surgically treated patients. Korean J Gastroenterol 2007;50:42-50

4. Di Ciaula A, Wang DQ, Portincasa P. An update on the pathogenesis of cholesterol gallstone disease. Curr Opin Gastroenterol 2018;34:71 80.

5. Cruz-Monserrate Z, Conwell DL, Krishna SG. The impact of obesity on gallstone disease, acute pancreatitis, and pancreatic cancer. Gastroenterol Clin North Am 2016;45:625-637.

6. Baik I. Forecasting obesity prevalence in Korean adults for the years
2020 and 2030 by the analysis of contributing factors. Nutr Res Pract 2018;12:251-257.

7. Abraham HD, Anderson C, Lee D. Somatization disorder in sphincter of Oddi dysfunction. Psychosom Med 1997;59:553-557.

8. Desautels SG, Slivka A, Hutson WR, et al. Postcholecystectomy pain syndrome: pathophysiology of abdominal pain in sphincter of Oddi type III. Gastroenterology 1999;116:900-905.

9. Dube SR, Fairweather D, Pearson WS, Felitti VJ, Anda RF, Croft JB. Cumulative childhood stress and autoimmune diseases in adults. Psychosom Med 2009;71:243-250.

10. Bettison TM, Nahm CB, Gill AJ, Mittal A, Malhi GS, Samra JS. Understanding the pathophysiology of psychological distress and pancreatic cancer: a systematic review. Pancreas 2018;47:376-381.

11. Clark KL, Loscalzo M, Trask PC, Zabora J, Philip EJ. Psychological distress in patients with pancreatic cancer--an understudied group. Psychooncology 2010;19:1313-1320.

12. Zabora J, BrintzenhofeSzoc K, Curbow B, Hooker C, Piantadosi S. The prevalence of psychological distress by cancer site. Psychooncology 2001;10:19-28.

13. Joffe RT, Rubinow DR, Denicoff KD, Maher M, Sindelar WF. Depression and carcinoma of the pancreas. Gen Hosp Psychiatry 1986;8:241245.

14. Massie MJ. Prevalence of depression in patients with cancer. J Natl Cancer Inst Monogr 2004;32:57-71.

15. Yaskin JC. Nervous symptoms as earliest manifestations of carcinoma of the pancreas. JAMA 1931;96:1664-1668.

16. Zhao D, Weng C. Combining PubMed knowledge and EHR data to develop a weighted bayesian network for pancreatic cancer prediction. J Biomed Inform 2011;44:859-868.

17. Kim JY, Chang HS, Kim MH, et al. A case of autoimmune chronic pancreatitis improved with oral steroid therapy. Korean J Gastroenterol 2002;39:304-308.

18. Lee HW, Moon SH, Kim MH, et al. Relapse rate and predictors of relapse in a large single center cohort of type 1 autoimmune pancreatitis: long-term follow-up results after steroid therapy with shortduration maintenance treatment. J Gastroenterol 2018;53:967-977.

19. Ryu JK, Chung JB, Park SW, et al. Review of 67 patients with autoimmune pancreatitis in Korea: a multicenter nationwide study. Pancreas 2008;37:377-385.

20. Pezzilli R, Pagano N. Pathophysiology of autoimmune pancreatitis. World J Gastrointest Pathophysiol 2014;5:11-17.

21. Hart PA, Zen Y, Chari ST. Recent advances in autoimmune pancreatitis. Gastroenterology 2015;149:39-51.

22. Sapolsky RM. Why zebras don't get ulcers. 3rd ed. p154-160, New York, Henry Holt and Company, 2004.

23. Majumder S, Takahashi N, Suresh T. Chari ST. Autoimmune pancreatitis. Dig Dis Sci 2017; 62:1762-1769.

24. Kamisawa T, Shimosegawa T, Okazaki K, et al. Standard steroid treatment for autoimmune pancreatitis. Gut 2009;58:1504-1507. 
25. Hart PA, Topazian MD, Witzig TE, et al. Treatment of relapsing autoimmune pancreatitis with immunomodulators and rituximab: the Mayo Clinic experience. Gut 2013;62:1607-1615.

26. Park $\mathrm{DH}, \mathrm{Kim} \mathrm{MH}, \mathrm{Oh} \mathrm{HB}$, et al. Substitution of aspartic acid at position 57 of the DQbeta1 affects relapse of autoimmune pancreatitis. Gastroenterology 2008;134:440-446.

27. Raczynska J, Habior A, Pączek L, Foroncewicz B, Pawelas A, Mucha K. Primary biliary cirrhosis in the era of liver transplantation. Ann Transplant 2014;19:488-493.

28. Chapman R, Fevery J, Kalloo A, et al. Diagnosis and management of primary sclerosing cholangitis. Hepatology 2010;51:660-678.

29. Apte MV, Pirola RC, Wilson JS. Mechanisms of alcoholic pancreatitis. J Gastroenterol Hepatol 2010;25:1816-1826.

30. Kamisawa T, Kuruma S, Chiba K, Tabata T, Koizumi S, Kikuyama M. Biliary carcinogenesis in pancreaticobiliary maljunction. J Gastroenterol 2017;52:158-163.

31. Juran $B D$, Lazaridis KN. Environmental factors in primary biliary cirrhosis. Semin Liver Dis 2014;34:265-272.

32. Lindor KD, Gershwin ME, Poupon R, et al. Primary biliary cirrhosis. Hepatology 2009;50:291-308.

33. Pandol SJ, Apte MV, Wilson JS, Gukovskaya AS, Edderkaoui M. The burning question: why is smoking a risk factor for pancreatic cancer? Pancreatology 2012;12:344-349.

34. Raimondi S, Maisonneuve P, Löhr JM, Lowenfels AB. Early onset pancreatic cancer: evidence of a major role for smoking and genetic factors. Cancer Epidemiol Biomarkers Prev 2007;16:1894-1897.

35. Aune D, Greenwood DC, Chan DS, et al. Body mass index, abdominal fatness and pancreatic cancer risk: a systematic review and nonlinear dose-response meta-analysis of prospective studies. Ann Oncol 2012;23:843-852.

36. Ilic M, llic I. Epidemiology of pancreatic cancer. World J Gastroenterol 2016;22:9694-9705.

37. Koyanagi YN, Matsuo K, Ito H, et al. Body-mass index and pancreatic cancer incidence: a pooled analysis of nine population-based cohort studies with more than 340,000 Japanese subjects. J Epidemiol 2018;28:245-252.

38. Guelrud M, Mendoza S, Rossiter G, Ramirez L, Barkin J. Effect of nifedipine on sphincter of Oddi motor activity: studies in healthy volunteers and patients with biliary dyskinesia. Gastroenterology 1988;95:1050-1055.

39. Small AJ, Kozarek RA. Sphincter of Oddi dysfunction. Gastrointest Endosc Clin N Am 2015;25:749-763.

40. O'Hara SP, Karlsen TH, LaRusso NF. Cholangiocytes and the environment in primary sclerosing cholangitis: where is the link? Gut 2017;66:1873-1877.

41. Okazaki K, Uchida K, Koyabu M, Miyoshi H, Takaoka M. Recent advances in the concept and diagnosis of autoimmune pancreatitis and IgG4-related disease. J Gastroenterol 2011;46:277-288.

42. Sasaki M, Kakuda Y, Miyakoshi M, Sato Y, Nakanuma Y. Infiltration of inflammatory cells expressing mitochondrial proteins around bile ducts and in biliary epithelial layer may be involved in the pathogenesis in primary biliary cirrhosis. J Clin Pathol 2014;67:470-476.

43. Breitbart W, Rosenfeld B, Tobias K, et al. Depression, cytokines, and pancreatic cancer. Psychooncology 2014;23:339-345.

44. Song HR, Woo YS, Bahk WM. Depression as an inflammatory disease. Korean J Psychopharmacol 2013;24:5-10.

45. Duhigg C. The power of habit. 1st ed. p3-30, New York, Random House, 2012.

46. Chrousos GP, Gold PW. The concepts of stress and stress system disorders. Overview of physical and behavioral homeostasis. JAMA 1992;267:1244-1252.

47. González-Díaz SN, Arias-Cruz A, Elizondo-Villarreal B, Monge-Ortega OP. Psychoneuroimmunoendocrinology: clinical implications. World Allergy Organ J 2017;10:19.

48. Reiche EM, Nunes SO, Morimoto HK. Stress, depression, the immune system, and cancer. Lancet Oncol 2004;5:617-625.

49. Reichlin S. Neuroendocrine-immune interactions. N Engl J Med 1993;329:1246-1253.

50. Szabo S, Tache $Y$, Somogyi A. The legacy of Hans Selye and the origins of stress research: a retrospective 75 years after his landmark brief "letter" to the editor\# of nature. Stress 2012;15:472-478.

51. Ekman P. Emotions revealed: recognizing faces and feelings to improve communication and emotional life. 2nd ed. p52-81, New York, Henry Holt and Company, 2007.

52. Toouli J, Baker RA. Innervation of the sphincter of Oddi: physiology and considerations of pharmacological intervention in biliary dyskinesia. Pharmacol Ther 1991;49:269-281.

53. Pavlov PI. Conditioned reflexes: an investigation of the physiological activity of the cerebral cortex. Ann Neurosci 2010;17:136-141.

54. Holmes TH, Rahe RH. The social readjustment rating scale. J Psychosom Res 1967;11:213-218.

55. Gantt WH. Principles of nervous breakdown-schizokinesis and autokinesis. Ann N Y Acad Sci 1953;56:143-163.

56. Lown B. The lost art of healing: practicing compassion in medicine. 2nd ed. p61-77, New York, Random House Publishing Groups, 1999.

57. Jin MJ, Kim JS, Kim S, Hyun MH, Lee SH. An integrated model of emotional problems, beta power of electroencephalography, and low frequency of heart rate variability after childhood trauma in a nonclinical sample: a path analysis study. Front Psychiatry 2017;8:314.

58. Kim S, Kim JS, Jin MJ, Im CH, Lee SH. Dysfunctional frontal lobe activity during inhibitory tasks in individuals with childhood trauma: an event-related potential study. Neuroimage Clin 2018;17:935-942.

59. Pena CJ, Kronman HG, Walker DM, et al. Early life stress confers lifelong stress susceptibility in mice via ventral tegmental area OTX2. Science 2017;356:1185-1188.

60. Danese A, S JL. Psychoneuroimmunology of early-life stress: the hidden wounds of childhood trauma? Neuropsychopharmacology 2017;42:99-114. 
61. Danese A, Tan M. Childhood maltreatment and obesity: systematic review and meta-analysis. Mol Psychiatry 2014;19:544-554.

62. Simonton OC, Matthews-Simonton S, Creighton JL. Getting well again. 1st ed. p56-78, New York, Bantam Books, 1992.

63. Yang $P$, Tao R, He C, Liu S, Wang Y, Zhang $X$. The risk factors of the alcohol use disorders-through review of its comorbidities. Front Neurosci 2018;12:303.

64. Lasser K, Boyd JW, Woolhandler S, Himmelstein DU, McCormick D, Bor DH. Smoking and mental illness: a population-based prevalence study. JAMA 2000;284:2606-2610.

65. Secades-Villa R, González-Roz A, García-Pérez A, Becoña E. Psychological, pharmacological, and combined smoking cessation interventions for smokers with current depression: a systematic review and meta-analysis. PLoS One 2017;12:e0188849.

66. Pereira-Miranda E, Costa PRF, Queiroz VAO, Pereira-Santos M, Santana MLP. Overweight and obesity associated with higher depression prevalence in adults: a systematic review and meta-analysis. J Am Coll Nutr 2017;36:223-233.

67. Blechert J, Michael T, Grossman P, Lajtman M, Wilhelm FH. Autonomic and respiratory characteristics of posttraumatic stress disorder and panic disorder. Psychosom Med 2007;69:935-943.

68. Segerstrom SC, Miller GE. Psychological stress and the human immune system: a meta-analytic study of 30 years of inquiry. Psychol Bull 2004;130:601-630.

69. Song H, Fang F, Tomasson $G$, et al. Association of stress-related disorders with subsequent autoimmune disease. JAMA 2018;319:23882400.

70. Maire F, Rebours V, Vullierme MP, et al. Does tobacco influence the natural history of autoimmune pancreatitis? Pancreatology 2014;14:284-288.

71. Hirano K, Tada M, Isayama H, et al. High alcohol consumption increases the risk of pancreatic stone formation and pancreatic atrophy in autoimmune pancreatitis. Pancreas 2013;42:502-505.

72. Al-Harthy N, Kumagi T, Coltescu C, Hirschfield GM. The specificity of fatigue in primary biliary cirrhosis: evaluation of a large clinic practice. Hepatology 2010;52:562-570.

73. Smyk DS, Rigopoulou El, Muratori L, Burroughs AK, Bogdanos DP. Smoking as a risk factor for autoimmune liver disease: what we can learn from primary biliary cirrhosis. Ann Hepatol 2012;11:7-14.

74. Shaheen AA, Kaplan GG, Almishri W, et al. The impact of depression and antidepressant usage on primary biliary cholangitis clinical outcomes. PLoS One 2018;13:e0194839.

75. Carlson LE, Angen M, Cullum J, et al. High levels of untreated distress and fatigue in cancer patients. Br J Cancer 2004;90:2297-2304.

76. Nan KJ, Wei YC, Zhou FL, et al. Effects of depression on parameters of cell-mediated immunity in patients with digestive tract cancers. World J Gastroenterol 2004;10:268-272.

77. Kim-Fuchs $C$, Le CP, Pimentel MA, et al. Chronic stress accelerates pancreatic cancer growth and invasion: a critical role for betaadrenergic signaling in the pancreatic microenvironment. Brain Behav Immun 2014;40:40-47.

78. Tilg H, Dinarello CA, Mier JW. IL-6 and APPs: anti-inflammatory and immunosuppressive mediators. Immunol Today 1997;18:428-432.

79. Valkanova V, Ebmeier KP, Allan CL. CRP, IL-6 and depression: a systematic review and meta-analysis of longitudinal studies. J Affect Disord 2013;150:736-744.

80. Bellone G, Smirne C, Mauri FA, et al. Cytokine expression profile in human pancreatic carcinoma cells and in surgical specimens: implications for survival. Cancer Immunol Immunother 2006;55:684-698.

81. Miao JW, Liu LJ, Huang J. Interleukin-6-induced epithelial-mesenchymal transition through signal transducer and activator of transcription 3 in human cervical carcinoma. Int J Oncol 2014;45:165-176.

82. Xie G, Yao Q, Liu Y, et al. IL-6-induced epithelial-mesenchymal transition promotes the generation of breast cancer stem-like cells analogous to mammosphere cultures. Int J Oncol 2012;40:1171-1179.

83. Morselli-Labate AM, Pezzilli R. Usefulness of serum IgG4 in the diagnosis and follow up of autoimmune pancreatitis: a systematic literature review and meta-analysis. J Gastroenterol Hepatol 2009;24:1536.

84. Zen Y, Fujii T, Harada K, et al. Th2 and regulatory immune reactions are increased in immunoglobin G4-related sclerosing pancreatitis and cholangitis. Hepatology 2007;45:1538-1546.

85. Uchida K, Okazaki K. Clinical and pathophysiological aspects of type 1 autoimmune pancreatitis. J Gastroenterol 2018;53:475-483.

86. Kaplan MM, Gershwin ME. Primary biliary cirrhosis. N Engl J Med 2005;353:1261-1273.

87. Hov JR, Boberg KM, Karlsen TH. Autoantibodies in primary sclerosing cholangitis. World J Gastroenterol 2008;14:3781-3791.

88. Hirschfield GM, Karlsen TH, Lindor KD, Adams DH. Primary sclerosing cholangitis. Lancet 2013; 382: 1587-1599.

89. Chan C, Lin HJ, Lin J. Stress-associated hormone, norepinephrine, increases proliferation and IL-6 levels of human pancreatic duct epithelial cells and can be inhibited by the dietary agent, sulforaphane. Int J Oncol 2008;33:415-419.

90. Schuller HM, Al-Wadei HA, Ullah MF, Plummer HK 3rd. Regulation of pancreatic cancer by neuropsychological stress responses: a novel target for intervention. Carcinogenesis 2012;33:191-196.

91. Shan T, Ma J, Ma Q, et al. $\beta 2-A R-H I F-1 \alpha$ : a novel regulatory axis for stress-induced pancreatic tumor growth and angiogenesis. Curr Mol Med 2013;13:1023-1034. 